As the interval between infection and the appearance of the rash in small-pox is generally 12 days the child was doubtless infected in utero and at the time when the mother was yet in the incubation stage. The time was too short for the immunity, which the mother's attack of small-pox is thought to confer on the child, to have been secured. 'The variola was also so far advanced that the vaccinia could not prevent but only modify and stay its progress. 'The termination showed that the type of the disease was a severe one, yet the vaccination undoubtedly held it in check for a period. Ilalifax.

\section{AN EXAMPLE OF ACCESSORY PANCREAS.}

BY G. GREY TURNER, F.R.C.S. ENG.

I RECENTLY found this anomaly in the course of a postmortem examination on a female, 15 years of age. Death followed an operation for lumbar abscess due to tuberculous disease of the spine. On the wall of the jejunum about 12 inches from its origin there was a small yellowish mass that might have easily been overlooked. Closer examination showed that the nodule was situated in the convexity of the gut exactly opposite the mesenteric attachment. It was roughly circular in outline, eight millimetres in diameter, and three millimetres thick. The surface was lobulated and was but slightly elevated under the peritoneum covering it. On opening the gut the mass was found to project to a greater extent under the mucous membrane than it did externally. Over its centre there was a well-marked ridge about three-cuarters of an inch long running in the axis of the bowel and surmounted by a papilla more definite than that at the opening of the common duct in to the duodenum. Leading from the gland there was a duct opening on the side of the ridge, not on the papilla. The cut surface of the gland had the appearance of normal pancreas, the lobules being very distinct. Microscopically, it exhibited the structure of normal pancreatic gland substance with well-developed ducts, but without cell islets. The lobules were loosely arranged, but there was no increase of interlobular tissue. The gland lay between a layer of normal mucous membrane on the one hand and of plain muscle on the other, suggesting that it had originated in the submucous tissues. There was no diverticulum in the bowel and the greater pancreas showed no abnormality.

The presence of an accessory pancreas is very well recognised and many cases are on record but it is certainly uncommon. Beyond their embryological interest these "rests" are significant, for they may sometimes b? the starting point of tumours in unusual situations. Mr. A. W. Mayo Robson and others give many references but with the exception of a case quoted by Dr. B. C. Stevens ${ }^{1}$ I have not noticed one lately in which details were given and on this ground the present case may be worth recording.

Newcastle-on-Tyne.

\section{SPINAL CATHETERISATION IN A CASE OF OBSTRUCTED LABOUR FROM CON- GENTTAL HYDROCEPHALCS.}

By Walter Allingham, M.R.C.S. ENG., L.R.C.P. Lond.

AN account of the following somewhat unusual method of effecting delivery may prove of interest.

The patient was a multipara, aged 40 years. Her previous pregnancies had been 12 in number, four of them terminating in miscarriages, three in the premature birth of hydrocephalic monsters, and the remaining five being normal. On the present occasion slue was nine months pregnant and latterly had suffered with very considerable dropsy. When called to sec her I was informed that she had been in severe labour for over 48 hours and that the child had been partially born for four hours. The patient was extremely exhausted and the pains were almost continuous. 'The body and arms of the child were delivered; there was no pulsation in the cord. Abdominal palpation showed that the uterus was still

1 Nicholls: Montreal Merlical Journal, December, 1900. Quoted by B. C. Stevens in his M.D. thusis (Durham) on Diseases of the Pancreas, of a very consiclerable size; there were no external signs of a twin, so in view of the patient's previous history the diagnosis of hydrocephalus was easy. I may here add in explanation that $I$ had just come from an extremely septic surgical case and was therefore averse to making any vaginal examination; so finding that all efforts to deliver the head in the usual way were unavailing I resolved to try spinal catheterisation as a means of evacuating the fluid in the fotal head, thus avoiding any introduction of hand or instruments by the vagina. With a small trocar equal in size to a No. 8 catheter I made a puncture in the dorsal region between the lamina of the vertebræ. Through the opening thus made I passed a No. 8 probe-pointed catheter, thence up the spinal cord. I cannot say it traversed the central canal of the corl, though its passage was quite easy. I was immediately rewarded by the flow of fluid from the catheter and a rapid diminution of the abdominal swelling. I regrel omitting to measure the quantity of fluid but roughly estimated it at about six pints. After this the head was delivered with ease, the patient making an excellent recovery. By evacuating the fluid in this way all risk of injuring the mother was avoided and the danger of infection was minimised.

Whiteparish, Salisbury, Wilts.

** It is interesting to observe that a very similar case was described by Dr. J. W. Ballantyne at a meeting of the Edinburgh Obstetrical Society reported in THE LANCET of Nov. 19th. p. 1422.-En. L.

\section{d attirror}

\section{HOSPITAL PRACTICE, BRITISH AND FOREIGN.}

Nulla autem est alia pro certo noscendi via, nisi quamplurimas et morborum et dissectionum historias, tum aliorum tum propria coilectas habere, et inter se comparare.-Morasani De Sed. et Caus. Morb., lib. iv., Procmium.

\section{ST. THOMAS'S HOSPITAL.}

A CASE OF SUCCESSFUL OPERATION ON A CEREBELLAR ABSCESS SE:ONDARY TO MIDULE-EAR DISEASE, TVITH SOME POINTS IN THE DIAGNOSIS.

(Under the care of Mr. H. Betham Robinson.)

A BoY, aged 13 years, was admitted into St. Thomas's Hospital on Nay 27th. Eight years before he had measles, since which date he had had a fotid discharge from the left ear. During the last three weeks there had been pain in the head and in the left ear. The ear discharge had stopped and there had been incessant vomiting and obstinate constipation. For the last two days he had been in a very drowsy condition. He had got rapidly thinner since the onset of his illness. On admission he complained of pain in his head which could not be specially localised. There was tenderness behind the left ear, with some cedema over the mastoid but no discharge. The membrana tympani was destroyed and the tympanum was filled with granulations. 'The pupils were equal reacting to light and to accommodation, the vessels of the fundi were rather full and tortuous, the edges of the discs were blurred, and the discs themselves were slightly swollen. The tongue and facial muscles were unaffected. I'he grip of the left hand was weaker than that of the right; the left knee-jerk was increased but the plantar reflexes were equal and normal. He tended to curl up on his right side. His temperature, which previously had been as high as $104^{\circ} \mathrm{F}$., on admission at $120^{\prime}$ clock noon was $100^{\circ}$; this rose before the operation in the afternoon to $102 \cdot 4^{\circ}$. His pulse was 94 and his respirations were 20 .

A curved incision was made behind the pinna and this was drawn well forwards with a gauze retractor passed through the meatus. 'The mastoid antrum was opened with a gouge and pus escaped; the posterior wall of the meatus was taken away and the antrum and tympanum were freely thrown into one. The pus appeared to come from the posterior part of the antrum and from the groove for the lateral sinus. The groove was opened up and the 